\title{
Royal Epiphanies in the Kingdom of Sicily
}

\author{
Frederick III of Aragón (1296-1337)
}

\author{
Mirko Vagnoni
}

On Monday 25 May 2015, The Guardian reported the news of the inauguration, before a jubilant audience in Ashgabat in Turkmenistan, of an equestrian statue of President Gurbanguly Berdymukhamedov. The work, cast in bronze and covered in 24-carat gold leaf, rises up more than 20 metres from the ground and is placed on a spur of white marble. Before him, his predecessor Saparmurat Niyazov had also portrayed himself in the form of a gold-plated statue. It was placed in the middle of the capital and, during the day, it rotated following the course of the sun. ${ }^{1}$

Political and psychoanalytic research has underlined that leadership, and the collective projects connected with it, must have material expression in society in order to have a durable effect. ${ }^{2}$ In other words, in order to create a relationship between himself and his followers and to encourage the latter to carry out his political projects, a leader needs to produce a tangible trace (a real presence) in which the group can materialize its acceptance of his power. From a semiotic, anthropological, historical, and art-historical point of view, it has been underlined that the representation (portrait) of the holder of power is a perfect example of the material symbols that influences and reinforces the approval of the leader and the group's acceptance of his leadership. ${ }^{3}$ In other words, the royal portrait is one of the tools thanks to which

1 The Guardian, 25 May 2015 (https://www.theguardian.com/world/2015/may/25/horse-turkm enistan-president-statute-berdymukhamedov. Accessed 2019 September 13).

2 Alexander S. Haslam, Stephen D. Reicher, and Michael J. Platow, Psicologia del leader. Identità, influenza e potere [The New Psychology of Leadership: Identity, Influence, and Power] (HoveNew York, 2011; repr. Bologna, 2013), pp. 279-91.

3 Antonio Pinelli, Gérard Sabatier, Barbara Stollberg-Rilinger, Christine Tauber, and Diane Bodart, "Le portrait du roi: entre art, histoire, anthropologie et sémiologie," Perspective. La revue de l'INHA 1 (2012), 11-28, esp. 11-12. On the political use of portraits of the holder of power, may I also point out this recent conference: Kopf und Körper - Evidenzen der Macht im Herrscherporträt des 14.-18. Jahrhunderts. Internationale Tagung, Zentralinstitut für Kunstgeschichte, Munich, 1-2 December 2017. 
a leader emotionally strengthens the bond that ties himself to the group, by creating a specific identity ${ }^{4}$ and also increasing the subjects' acceptance of his figure. ${ }^{5}$

This is one of the reasons why dictators tend to circulate their portraits in society and, in the same way, it is why, when their regimes fall, the supporters of the new political order promptly destroy these same images. ${ }^{6}$ The news is full of such examples. To quote some recent episodes, we point out the demolition of the statues of: Enver Hoxha in Tirana, Albania, on 20 February 1991; Saddam Hussein in Baghdad, Iraq, on 9 April 2003; Hafez al-Assad (the father of the current president) in Daraa, Syria, on 25 March 2011; Muammar Gaddafi in Tripoli, Libya, on 23 August 2011; and Lenin in Kiev and Kharkiv, Ukraine, on 8 December 2013 and 28 September 2014, respectively. ${ }^{7}$

More specifically, coming to royal portraits, ${ }^{8}$ we have to note that research on the origin of the state in a modern sense has stressed that the institutional achievement of monarchic authority passes through the absence of the king's material body from public space and, on the contrary, the presence of a pictorial body represented on coins, medals, statues, and portraits in general. ${ }^{9}$ For his part, Brigitte Bedos-Rezak has highlighted that the beholders can perceive

4 Francesco Benigno, Parole nel tempo. Un lessico per pensare la storia (Rome, 2013), pp. 31-56.

5 For a recent summary of the concepts of 'leader' and 'leadership,' see:Joseph Nye, The Powers to Lead (New York, 2008); Haslam et al., Psicologia del leader; Benigno, Parole nel tempo, pp. 141-62.

6 Haslam et al., Psicologia del leader, p. 290.

7 Corriere della Sera, 29 August 2011 (https://www.corriere.it/cultura/11_agosto_29/canf ora-abbattere-statue-vandali-rivoluzioni_acacodbo-d22a-11eo-a2o5-8c1eg8b416f7.shtml. Accessed 2019 September 13); "Agenzia Nazionale Stampa Associata," 29 September 2014 (http://www.ansa.it/sito/photogallery/primopiano/2014/og/29/quando-cadono-le-statue -_41d287f4-eec7-4e96-93ad-9c497ea4cdic.html. Accessed 2019 September 13).

8 I would like to clarify that, in this paper, the term 'portrait' is not used in its modern meaning but as a synonym for a royal image and depiction: Stephen Perkinson, The Likeness of the King. A Prehistory of Portraiture in Late Medieval France (Chicago, 2009); Dominic Olariu, La genèse de la représentation ressemblante de l'homme. Reconsidérations du portrait à partir du XIIIe siècle (Bern, 2013).

9 Louis Marin, Le portrait du roi (Paris, 1981); Louis Marin, Des pouvoirs de l'image. Gloses (Paris, 1993); Louis Marin, Politiques de la représentation (Paris, 2005). And in general: Giovanni Careri, "Louis Marin: pouvoir de la représentation et représentation du pouvoir," in Louis Marin: le pouvoir dans ses représentations, eds. Giovanni Careri, and Xavier Vert (Paris, 2008), pp. 4-15, esp. 5. For a recent analysis in this direction, see: Jean-Marie Le Gall, "L'impossible invisibilité du roi de France 1450-16oo," in Il Principe invisibile. La rappresentazione e la riflessione sul potere tra Medioevo e Rinascimento. Proceedings of the International Conference, Mantua, 27-3o November 2013, eds. Lucia Bertolini, Arturo Calzona, Glauco Maria Cantarella, and Stefano Caroti, (Turnhout, 2015), pp. 453-70. 
an image as the real presence of the depicted subject. ${ }^{10}$ In addition, art historians have often underlined the ability of an image to recall something that is not present but in the mind of the beholder - in the same way as sacred images evoke the corporally invisible presence of saints to worshippers. ${ }^{11}$ In this sense, therefore, royal depictions too could arouse the same emotions and feelings of devotion that sacred images produce in their beholders.

In light of these considerations, this paper aims to verify if, among the different ways that a king had to be symbolically present and visible toward his subjects, ${ }^{12}$ Frederick III of Aragón, King of Sicily from 1296 to $1337,{ }^{13}$ used his own representation in order to spread his own image in his kingdom and, in this way, stimulate his subjects' acceptance of the Crown. In other words, the goal is to assess whether he used his own portrait as a sort of political tool in order to reinforce his power. To do this, I will first try to understand how much Frederick III made use of his portrait by identifying every official image of this king - namely, every portrait directly commissioned by the Crown. This will be

10 Brigitte Miriam Bedos-Rezak, When Ego Was Imago. Signs of Identity in the Middle Ages (Leiden-Boston, 2011).

11 Stephen Perkinson, "Rethinking the Origins of Portraiture," Gesta 46/2 (2007), 13558. For some examples of analyses of the memorial function of the medieval portrait, see: Christine Sauer, Fundatio und Memoria. Stifter und Klostergründer im Bild, 1100 bis 1350 (Göttingen, 1993); Caroline Horch, Der Memorialgedanke und das Spektrum seiner Funktionen in der bildenden Kunst des Mittelalters (Königstein im Taunus, 2001). On sacred images, instead, see, for example: Hans Belting, Bild und Kult. Eine Geschichte des Bildes vor dem Zeitalter der Kunst (Munich, 1990); Michele Bacci, Pro remedio animae: immagini sacre e pratiche devozionali in Italia centrale (secoli XIII e XIV) (Pisa, 200o).

12 Il Principe invisibile, eds. Bertolini et al.

13 On Frederick III of Aragón, see: Francesco Testa, Vita e Opere di Federico II re di Sicilia, ed. Elio Spinnato, introduction by Salvatore Fodale (original edition, De vita et rebus gestis Federici II Siciliae Regis, Palermo, 1775; Palermo, 2006); Antonino De Stefano, Federico III d'Aragona re di Sicilia (1296-1337) (Palermo, 1937; repr. Bologna, 1956); Rafael Olivar Bertrand, Un rei de llegenda. Frederic III de Sicilia (Barcelona, 1951); and above all Clifford R. Backman, Declino e caduta della Sicilia medievale. Politica, religione ed economia nel regno di Federico III d'Aragona Rex Siciliae (1296-1337) [The decline and fall of Medieval Sicily. Politics, religion, and economy in the reign of Frederick III, 1296-1337], ed. Alessandro Musco (Cambridge, Eng., 1995; updated repr. Palermo, 2007). The latter text is updated in: Clifford R. Backman, "Federico III d'Aragona: un regno rivisitato," in Il Mediterraneo del '3oo ed il regno di Federico III d'Aragona: saperi, economia, società. Proceedings of the International Conference, Palermo, Castelbuno, 29June-1 July 2006, ed. Alessandro Musco, Schede Medievali. Rassegna dell'Officina di Studi Medievali 49 (2011), pp. 7-14, however, confirming the previous interpretations. For a short summary, see: Salvatore Fodale, s.v.: "Federico III d'Aragona, re di Sicilia," in Dizionario Biografico degli Italiani 45 (Rome, 1995). A recent, but not particularly worthy, summary can be found in: Pasquale Hamel, Il lungo regno. Vita avventurosa di Federico III, re di Sicilia (Soveria Mannelli, 2014). 
possible thanks to a combined investigation of material and written sources because while some artefacts may have been lost, the images could be quoted in some contemporary chronicles. In a second step, I will analyse these images with a special focus on their dimensions, stylistic and iconographic accuracy in the rendering of the royal body, placement, and visual impact.

\section{The Identification of Official Images}

From the corpus of official images of Frederick III, we obviously have to leave out what was made both before his royal coronation and after his death. The first group includes, for instance, the seal used when he was acting lieutenant for his brother James II of Aragón, King of Sicily from 1285 to $1295 .{ }^{14}$ Instead, the illumination of the Consuetudines et statuta nobilis civitatis Messane falls into the second group..$^{15}$ Moreover, we have to exclude some images quoted in written texts, about whose dating or commissioning we do not have any certain information. Following an epistle written by Nicolò Speciale, a statue of the Aragonese king was placed in the Cathedral of Syracuse:

he [namely, Frederick III of Aragón] who is called third and older, whose statue it is possible to see in your [referring to the addressee of the epistle, namely, the Syracusan master in theology Bartolomeo] Syracuse, in the main temple. ${ }^{16}$

However, Nicolò Speciale was a political member of the court of Alfonso the Magnanimous, King of Sicily from 1416 to 1458 , and the above-mentioned letter dates back to 1436 - namely, 99 years after the death of Frederick III. ${ }^{17}$ What dating can be given to the quoted statue? Did the Aragonese king order it

14 Ferrán De Sagarra, Sigillografía Catalana. Inventari, descripció $i$ estudi dels segells de Catalunya, 3 vols (Barcelona, 1915-32), 1:241, n. 188, Messina, 7 November 1294. Impression on brown wax, diameter 50 mm. Valencia, Arxiu del Capítol de la Sèu, n. o.738. A similar example is in the Arxiu de la Corona d'Aragó.

15 Angela Daneu Lattanzi, I manoscritti ed incunaboli miniati della Sicilia, 2 vols (RomePalermo, 1965-84), 2:185-186 and fig. XXXII, Re Federico III, illumination, after the first quarter of the 14th century. Palermo, Biblioteca Comunale, Ms. 2 Qq. E. 140, Consuetudines et statuta nobilis civitatis Messane, fol. $6 \mathrm{v}$, in the field of the initial I.

16 "qui tertius et senior dictus est, cuius statua apud vestras Syracusas in maiori templo conspicitur": Cronache siciliane inedite della fine del Medioevo, ed. Francesco Giunta (Palermo, 1955), Epistola Nicolai de Speciali de genologia regum, p. 84.

17 On this author and his work, see: Cronache siciliane inedite, ed. Giunta, pp. 23-27. 
directly? Unfortunately, the author of the text says nothing about this, nor do we have any other information about this artefact.

On 8 May 1318, the fourth child of Frederick III was born in Mazara del Vallo and baptized in the cathedral of the same city. A local tradition has it that, on this occasion, the king ordered a large picture of the event to be placed close to the baptistery. ${ }^{18}$ Once again in this case, from the information that we have, it is very difficult to determine whether Frederick III actually ordered this work himself. For this reason, it is better not to include it in the list of his official portraits. Hence, all in all, regarding Frederick III we have four representations: the royal seal, the billon silver denaro coin, the lost mosaic from the Church of Santa Maria della Valle (known as della Scala or Badiazza) near Messina, and the mosaic in the Cathedral of Messina. Below, I will analyse these images in detail.

The work by Francesco Daniele on the royal sarcophagi of the Cathedral of Palermo, published in 1784, reported the discovery of a golden bull of Frederick III of Aragón and also included a drawing of it. The bull was in the Archivio di Castel Sant'Angelo but detached from its original diploma. ${ }^{19}$ At a later date, this archive was moved into the Archivio Segreto Vaticano and all traces of the bull were lost. That is until 11 February 1883, when Antonio Salinas, in a session of the Società Siciliana per la Storia Patria, announced its recovery and, on the basis of its legend, ascribed it to Frederick IV of Aragón, King of Sicily from 1355 to $1377 .{ }^{20}$ After that, Pietro Sella in $1934^{21}$ and Aldo Martini in $1984^{22}$

18 "Del quadro in cui era riprodotta la cerimonia del battesimo colla seguente iscrizione: Rogerius, Fiderici II et Eleonore regine filius, hic Mazariae ortus et renatus a 1318 die 8 maii rimane una copia fatta nel 1618 e restaurata nel 1712": Filippo Napoli, Storia della Città di Mazara (Mazara, 1932), pp. 67-68. In this regard, see: Antonino Marrone, "La corte itinerante di Sicilia negli anni 1282-1377," in Il Mediterraneo del '30o ed il regno di Federico III d'Aragona, ed. Musco, pp. 149-92.

19 Francesco Daniele, I regali sepolcri del Duomo di Palermo. Riconosciuti e illustrati (Naples, 1784); anastatic reprint of the 1859 edition in: Il sarcofago dell'imperatore. Studi, ricerche e indagini sulla tomba di Federico II nella Cattedrale di Palermo, 1994-1999, 3 (Palermo, 2002), pp. 123-24.

20 The minutes of the session are published in Archivio Storico Siciliano n.s. 8 (1883), Atti della Società, session of 11 February 1883, pp. 248-49.

21 Le bolle d'oro dell'Archivio Vaticano, ed. Pietro Sella (Vatican City, 1934), p. 53, n. 19.

22 I sigilli d'oro dell'Archivio Segreto Vaticano, ed. Aldo Martini, historical note by Martino Giusti and preface by Alessandro Pratesi (Milano, 1984), p. 68, fig. 20. During a restoration, 
confirmed this interpretation in their inventories of the golden bulls of the Archivio Segreto Vaticano.

Therefore, it is clear that the above-mentioned bull is not related to Frederick III; furthermore, there are not any other items connected with this king in the Archivio Segreto Vaticano. Indeed, there are no such references either in the inventory of the seals made between 1937 and 1946 by Pietro Sella, ${ }^{23}$ or in the 2013 update by Luca Becchetti. ${ }^{24}$ The only exception is a seal of Frederick III but with a representation of Hercules instead of the king. ${ }^{25}$ The item - round, in red wax, and with a diameter of $22 \mathrm{~mm}$ - is housed in a little wooden box without a lid. A white and red ribbon attaches it to a power of attorney contract, dated 17 October 1305 (AA. Arm. I-XVIII, 4459). The legend has the inscription "INICIVM - SAPIENCIE - TIMOR • DOMINI." From the iconographic point of view, it has an image of Hercules with a club and lion skin and, on the sides, the letters " $\mathrm{F}=\mathrm{T}$ " (namely, Fridericus Tertius) and dots around the image and the legend. Something similar is also present in the collection of seals made by Louis Douët d'Arcq in 1868. Indeed, this book quotes a round seal of Frederick III hanging from a letter of credence dated Messina, 29 May 1306 (Archives de l'Empire J. 408, n. 13). ${ }^{26}$ It has a very close diameter of $25 \mathrm{~mm}$ and the same legend as the Roman item. This type is probably the secret seal generally used for the private correspondence of the king. We have written proof of this in a letter of 7 July 1308 from Frederick III to James II, which is sealed "sub parvo sigillo nostro secreto," ${ }^{27}$ or in another letter, addressed to the citizens of Palermo in 1314, "data apud Castrum Iohannis, sub parvo sigillo nostro secreto."28

However, researchers of diplomatics also attest to the use of a main seal to corroborate documents issued by the royal chancellery. ${ }^{29}$ Nevertheless, for

the bull was finally reunited with its original document, issued in Messina on 17 December 1373 (shelf mark: A.A.Arm. I-XVIII, 511).

23 I sigilli dell'Archivio Vaticano, ed. Pietro Sella, in collaboration with Marie-Hyacinthe Laurent, 2 vols (Vatican City, 1937-46).

24 Luca Becchetti, I sigilli dell'Archivio Segreto Vaticano. Nuove ricerche sfragistiche (Vatican City, 2013).

25 I sigilli dell'Archivio Vaticano, ed. Sella, p. 329, n. 1062, image in plate LXXXI, fig. 1062.

26 Louis Douët d'Arcq, Collection de sceaux. Archives de l'Empire. Inventaires et documents, 3 , ed. M. Le Marquis de Laborde (Paris, 1868), p. 511, n. 11770.

27 Backman, Declino e caduta della Sicilia, p. 258, n. 51.

28 Cronaca della Sicilia di Anonimo del Trecento, ed. Pietro Colletta (Enna, 2013), p. 188. But there are other similar examples in this text.

29 For example, the catalogue for the exhibition on the Messina documents of the Fundación Casa Ducal de Medinaceli in Seville quotes a document from 12 July 1332 with a hanging seal (however, it was later lost): Messina. Il ritorno della memoria. Exhibition Catalogue, 
our purposes, it is crucial to verify whether it had the image of the king or not. In a paper of 1997, Maria Grazia Fallico listed some diplomas of Frederick III bearing a seal. ${ }^{30}$ In particular, these consisted of a parchment from 1320 of the Commenda della Magione section of the Archivio di Stato di Palermo; ${ }^{31}$ two parchments of the city of Messina issued on 1 October 1302 and stored in the Archivio ducale Medinaceli in Toledo; and four parchments of the city of Caltagirone issued in 1299 and stored in the Museo Civico di Caltagirone, in the parchments section of the Universitas di Caltagirone.

To my knowledge, reproductions of these seals have never been published. However, thanks to the kind help of archivists Margherita Dizia and Enzo Piluso, I was able to examine the items in Caltagirone. All of the four examples from this location are identical. They are red wax hanging seals placed in a wooden box (Figure. 6.1). The legend has the inscription "FRIDERICUS TERCIUS DEI GRACIA REX SICILIE DUCATUS APULIE ET PRINCIPATUS CAPUE," and the image displays the king on a horse facing left. The sovereign is wearing a helmet with a crown, and he has a sword in his right hand and a shield in his left. Both the latter and the caparison of the horse bear the coat of arms of the dynasty: quartered, with the red bars in field gold of Aragón and the black eagle in field argent of Sicily.

Without a doubt, this image is an official representation of Frederick III and its mobile support would have facilitated its circulation throughout the kingdom. In this way, it could reach a large number of subjects. However, we should consider that seals were not made to move around but to be stored, along with their documents, in the archives of their recipients. ${ }^{32}$ Moreover,

Rome, Museo Nazionale di Castel Sant'Angelo, September 1994, ed. Grazia Fallico, (Palermo, 1994), p. 183, document n. 77 .

30 Maria Grazia Fallico, "Le fonti archivistiche (1296-1337)," in Federico III d'Aragona, re di Sicilia (1296-1337). Proceedings of the International Conference, Palermo, 27-30 November 1996, eds. Massimo Ganci, Vincenzo D’Alessandro, and Rosa Scaglione Guccione, Archivio Storico Siciliano S. IV, 23 (1997), 59-80, esp. 69-70.

31 In reality, in the inventory of the archive there is only one document for 1320, and it is not of Frederick III: Il Tabulario della Magione di Palermo (1116-1643). Repertorio, ed. Elisabetta Lo Cascio (Rome, 2011), p. 315, card n. 596. The diploma in question, instead, is n. 6o6, from 29 July 1329: Il Tabulario della Magione di Palermo, ed. Lo Cascio, p. 324, card n. 613. And the Repertorio points out the absence of the seal, which has also been kindly verified by Dr. Serena Falletta, archivist at the branch of the Catena of the Archivio di Stato di Palermo.

32 Robert-Henri Bautier, s.v. "Bolla," in Enciclopedia dell'Arte Medievale 3, ed. Angiola Maria Romanini (Rome, 1992); Michel Pastoureau, "Les sceaux et la fonction sociale des images," in L'image. Fonctions et usage des images dans l'Occident medieval. Proceedings of the 6th International Workshop on Medieval Society, Erice, 17-23 October 1992, eds. Jérôme Baschet, 
their dimensions - although Frederick III's seals were larger than those of the Norman predecessors and in line with those of the Swabian and Aragonese traditions ${ }^{33}$ - were somewhat reduced and certainly of scarce visual impact. Finally, their use was not particularly common either. Owing to the various political vicissitudes that characterized the reign of Frederick III, the royal title changed over the years. ${ }^{34}$ The seal probably had to adapt itself to these alterations. Nevertheless, due to the small number of items preserved, it is not possible to verify whether there were changes in the iconography or whether the seal-type with the royal image was used for all 41 years of his reign. In any case, even if this kind of choice had been made, we should note that the average number of issues does not seem to have been very high.

Historians have reported, on one hand, the loss of a large amount of documents related to this period of Aragonese history, while, on the other hand, they have underlined that the administration was reorganized and the royal chancellery improved during the reign of Frederick III. ${ }^{35}$ However, on the basis of the number of documents (letters, warrants, pre-emptions) identified in researches on diplomatics, we have respectively 218 annual issues for Peter III (r. 1282-1285); 112 for James II; 25 for Frederick III, both independently and together with Peter II; 52 for Peter II (r. 1337-1342); 38 for Louis (r. 1342-1355); 311 for Frederick IV; and 1 for Mary I (r. 1377-1401). ${ }^{36}$ The number related to Frederick III is decisively low in comparison with the other Aragonese kings, but it is also small in comparison with Swabian predecessors. Only the Normans had more limited issues, although they ruled a wider kingdom. Indeed, the general situation is as follows: 5.9 diplomas under Roger II (r. 1130-1154); 7.9 under

and Jean-Claude Schmitt (Paris, 1996), pp. 275-308; Stefania Ricci, John William Nesbitt, and François Richard, s.v. "Sigillo," in Enciclopedia dell'Arte Medievale 10, ed. Angiola Maria Romanini (Rome, 1999).

33 The diameter of the seals of the Norman kings varies between 25 and $35 \mathrm{~mm}$. Instead, the Swabian and Aragonese seals can be as large as 95-110 mm; see: Mirko Vagnoni, Epifanie del corpo in immagine dei re di Sicilia (1130-1266), introduction by Giovanni Travagliato (Palermo, 2019), passim; Sagarra, Sigillografía Catalana, 1:207-209. A specimen of James II of Aragón, identical to that of Frederick III from an iconographic point of view, has a diameter of 70 mm. Sagarra, Sigillografía Catalana, 1:209, n. 38 .

34 Pietro Colletta, Storia, cultura e propaganda nel regno di Sicilia nella prima metà del XIV secolo: la Cronica Sicilie (Rome, 2011), pp. 191-92.

35 Codice diplomatico dei re aragonesi di Sicilia Pietro I, Giacomo, Federico II, Pietro e Ludovico dalla rivoluzione siciliana del 1282 sino al 1355, con note storiche e diplomatiche, ed. Giuseppe La Mantia, 2 vols (Palermo, 1917-56), 1:VII-CCXV.

36 Antonino Marrone, I registri della R. Cancelleria e del Protonotaro del Regno di Sicilia (Palermo, 2012); Antonino Marrone, Repertorio degli atti della Cancelleria del Regno di Sicilia dal 1282 al 1390 (Palermo, 2012), in particular, for the recapitulatory table, see p. 5 . 
William I (r. 1154-1166); 10.4 under William II (r. 1166-1189); 37.3 under Henry VI (r. 1194-1197); 48 under Frederick II (r. 1198-1250), also including the imperial lands but excluding the deperdita; and 35.8 under Manfred (r. 1258-1266). ${ }^{37}$

If we also consider that the same recipients could receive several documents, we can suppose that the number of subjects involved was not particularly great. ${ }^{38}$ Therefore, in line with these data, it was not very frequent to be able to see the royal image of the seal and only a limited number of people would have had this opportunity.

Among the official representations of Frederick III, there is also the image of the billon silver denaro minted in Messina (Figure. 6.2). ${ }^{39}$ On the obverse of this coin is the legend “+ FRI - T - DEI - GRA" (namely, Fridericus tertius Dei Gratia), with the crowned head of the king turned to the left encircled in small pearls. Instead, the reverse displays the inscription "+ REX: SICILIE:" and a cross pattée again encircled by small pearls. We do not know if the denaro also continued to be issued during the years when the king adopted the title of Rex Trinacrie, namely, from 1311 to 1314 and from 1319 to $1320 .{ }^{40}$ However, it is plausible that it circulated for all the years of Frederick III's rule. Certainly, on a coin, the royal image could move around the entire kingdom - that is, the island of Sicily and part of Calabria - and the lower worth of a silver coin, in comparison with a gold coin, would have made its use more widespread. Moreover, we know that, probably around 1315, Frederick III implemented a monetary policy in order to place stricter royal control on the circulation and actual quality of currency. ${ }^{41}$ In addition, he ordered an abundant amount of silver coins to be minted while, at the same time, limited the minting of gold coins. ${ }^{42}$

37 Vagnoni, Epifanie del corpo, passim.

38 Moreover, note that the number of preserved diplomas is greater for the lay archives than for the ecclesiastical archives (Fallico, "Le fonti archivistiche"). On this basis, can we argue that there were more documents for the first than for the second?

Rodolf Spahr, Le monete siciliane dagli Aragonesi ai Borboni (1282-1836) (Palermo, 1959), p. 15 and image in plate II, n. 36; Philip Grierson, and Lucia Travaini, Medieval European Coinage. With a Catalogue of the Coins in the Fitzwilliam Museum, Cambridge, 14. Italy 3. South Italy, Sicily, Sardinia (Cambridge, Eng., 1998), pp. 267-68, and 698 and plate 43, images n. 780-82.

40 Colletta, Storia, cultura e propaganda, pp. 191-92.

41 Hamel, Il lungo regno, pp. 87-88.

42 Spahr, Le monete siciliane, p. 11; Grierson, and Travaini, Medieval European Coinage, pp. 265-68, esp. $257-6$ o. 
Considering that the former also included the denari with the king's head, ${ }^{43}$ the possibility of coming across the royal image will have been quite high. No doubt, it was more likely than in the past: Peter III did not use coins with the royal portrait, while James II began to mint denari both with and without his image (although the latter are very rare). ${ }^{44}$

Nevertheless, coins could be hoarded and, moreover, anthropologists have noted that, in general, when coins are used, more attention is placed on their economic worth than on their images. ${ }^{45}$ Moreover, we have to also consider that the denaro is very small, with a diameter of only $16 \mathrm{~mm}$ and a weight of between 0.58 and $0.65 \mathrm{~g}$, and it has a certain iconographical inaccuracy and stylization that makes it difficult to identify the subject that is represented. It is certain that it did not have a particularly great visual or emotional impact; for example, it bore no comparison to the augustale of Frederick II. Indeed, the Swabian emperor gave this coin a very wide circulation (even beyond the kingdom) and dissemination (even greater thanks to the issue of the mezzo augustale), and he paid particular attention toward the iconographic rendering of the royal image. ${ }^{46}$ It is symptomatic that a substantial number of these is still preserved ( 334 for the augustale and 88 for the mezzo augustale), and the exceptionality of this coin was clearly perceived by the contemporary chroniclers, who quoted and described it in their texts. ${ }^{47}$

\section{The Mosaic of the Church of Santa Maria della Valle in Messina}

The Church of Santa Maria della Valle, also called della Scala or Badiazza, with the connected convent of Benedictine nuns (these days, the congregation is

43 Spahr, Le monete siciliane, pp. 12-16; Grierson, and Travaini, Medieval European Coinage, pp. 265-68, 696-99, plates 42-43, images n. 771-82.

44 Spahr, Le monete siciliane, pp. 3-10; Grierson, and Travaini, Medieval European Coinage, pp. 26o-64, 694-97, plates 41-42, images n. 756-7o.

45 Michel Pastoureau, "L'État et son image emblématique," in Culture et idéologie dans la genèse de l'État moderne. Proceedings of the International Conference, Rome, 15-17 October 1984, eds. Jean-Claude Maire Vigueur, and Charles Pietri (Rome, 1985), pp. 145-53; Michel Pastoureau, "Le sceau médiéval," in Michel Pastoureau, Figures et couleurs. Étude sur la symbolique et la sensibilité médiévales (Paris, 1986), pp. 71-87; Lucia Travaini, s.v. "Moneta," in Enciclopedia dell'Arte Medievale 8, ed. Angiola Maria Romanini (Rome, 1997).

46 Lucia Travaini, s.v. "Augustale," in Enciclopedia fridericiana 1, ed. Ortensio Zecchino (Rome, 2005); Lucia Travaini, s.v. "Monetazione," in Enciclopedia fridericiana 2, ed. Zecchino; Vagnoni, Epifanie del corpo, pp. 91-94 (with more bibliographical details).

47 Ryccardi de Sancto Germano notarii, Chronica. Rerum Italicarum Scriptores II, 7/2, ed. Carlo Alberto Garufi (Bologna, 1937), pp. 181-82; Giovanni Villani, Nuova Cronica, ed. Giuseppe Porta, 3 vols (Parma, 1990-91), 1, 7.21, pp. 301-02. 
almost nil) is in Contrada Badiazza near Scala, in a mountainous area along the San Rizzo stream, approximately three miles from the centre of Messina. ${ }^{48}$ The current building, probably constructed on pre-existing remains, goes back to the end of the Norman domination or to the beginning of the Swabian rule. In particular, Giuseppe Agnello has proposed a dating to the first quarter of the $13^{\text {th }}$ century. ${ }^{49}$ However, following a fire during the Sicilian Vespers (1282), Frederick III ordered the church to be restored, redecorated, and perhaps also extended in the first decade of the 14th century. It was during this work that, as Placido Samperi asserted in 1644, the king commissioned a mosaic portrait of himself for the main apse (Figure. 6.3) in the act of offering, together with his wife, a model of the church to Saint Peter. ${ }^{50}$

Of this mosaic, we have only a fragment of the face of Saint Peter (now in the Museo Regionale di Messina, inv. n. 967). Following some considerations by Demetrio Salazaro ${ }^{51}$ and Ugo Monneret de Villard, ${ }^{52}$ Ferdinando Bologna, in 1969, proposed dating this artefact to the beginning of the 13th century and identified the subject as Frederick II of Swabia. ${ }^{53}$ However, by mutual consent, art historians later allocated this fragment (now there is uncertainty as to

48 Guido Di Stefano, "Larchitettura religiosa in Sicilia nel sec. XIII," Archivio storico Siciliano 4-5 (1938-39), 39-92, esp. 51-6o; Stefano Bottari, Monumenti svevi di Sicilia (Palermo, 1950), pp. 3-8; Fabio Basile, "La chiesa di S. Maria della Valle a Messina 'La Badiazza'. Una datazione da rivedere," Quaderno dell'Istituto dipartimentale di architettura e urbanistica dell'Università di Catania 4 (1972), 9-34; Giuseppe Spatrisano, Lo Steri di Palermo e l'architettura siciliana del Trecento (Palermo, 1972), pp. 256-58; Antonino Principato, Badiazza. La chiesa di S. Maria della Scala nella Valle a Messina (Messina, 1991); Stefan Tebruck, "Die sizilischen Klöster S. Maria in Valle Josaphat in Messina und S. Maria Latina in Agira und ihr sächsischer Fernbesitz," in Italien-Mitteldeutschland-Polen. Geschichte und Kultur im europäischen Kontext vom 10. bis zum 18. Jahrhundert, eds. Wolfgang Huschner, Enno Bünz, Christian Lübke, and Sebastian Kolditz (Leipzig, 2013), pp. 361-84.

49 Giuseppe Agnello, "S. Maria della Valle o la 'Badiazza' in Messina," Palladio. Rivista di Storia dell'Architettura n.s. 3 (1953), 49-66; Giuseppe Agnello, L'architettura civile e religiosa in Sicilia nell'età sveva (Rome, 1961), pp. 247-84.

$5^{\circ}$ "Hebbe in molta veneratione questo luogo Federico II d'Aragona Rè di Sicilia, et ingrandì quel Monasterio, et edificò quel Tempio, con bellissima architettura, ornando la Tribuna maggiore, con ricco Mosaico, ove egli dipinto si vede riverentemente à piè del Vicario di Christo S. Pietro Apostolo, con la Regina sua moglie, e tiene il modello del Tempio, e Monasterio nella man destra in atto di presentarglielo": Placido Samperi, Iconologia della gloriosa vergine Madre di Dio Maria, protettrice di Messina (Messina, 1644), p. 317.

$5^{1}$ Demetrio Salazaro, Studi sui monumenti dell'Italia Meridionale dal IV al XIII secolo, 2 vols (Naples, 1871-77), 2:68.

$5^{2}$ Ugo Monneret de Villard, "Note d'architettura messinese," Vita d'Arte. Rivista mensile d'Arte antica e moderna 2 (1909), 71-80, esp. 72.

53 Ferdinando воlogna, I pittori alla corte angioina di Napoli (1266-1414). E un riesame dell'arte nell'età fridericiana (Rome, 1969), pp. 22-23. 
the identity of the apostle) to the beginning of 14 th century, ${ }^{54}$ thus following Samperi's testimony. If it is plausible that the king represented in the apse of the Church of Santa Maria della Valle was Frederick III, it is also possible that he directly ordered its creation. Indeed, it seems that the Sicilian kings had an intense relationship with this monastery: first the Normans and then the Swabians granted it privileges and donations, and Peter III of Aragón was also particularly tied to it. ${ }^{55}$ Bartolomeo di Neocastro tells that this king visited the church on his way to Messina, immediately after the liberation of the city from the siege of Charles I of Anjou (1282):

[Peter III of Aragón] finally arrived at the threshold of the Sacred House of the Blessed Virgin della Scala; he empathized with the sad house, which he discreetly honoured but which the inequity of the enemy [had] ruined. ${ }^{56}$

The people of Messina attended and particularly venerated this church because there was a miraculous image of the Virgin, the depiction of the Madonna della Scala, ${ }^{57}$ on its main altar. For this reason, it also received gifts from foreign princes and queens. In confirmation of the intense relationship between the monarchy and this church, in 1633 the abbess Livia De Gregorio established that every week a mass be celebrated for the dead and living kings of Sicily who, thanks to their donations, had contributed to the church's wealth. ${ }^{58}$

54 Giuseppe Consoli, Messina. Museo Regionale (Bologna, 1980), pp. 2-3; Valentino Pace, "Pittura bizantina nell'Italia meridionale (secoli XI-XIV)," in I Bizantini in Italia, ed. Guglielmo Cavallo (Milan, 1982), pp. 427-94, esp. 489; Francesca Campagna Cicala, Il Museo regionale di Messina. Breve guida alla lettura delle opere (Messina, 1984), p. 9; Federico Zeri, and Francesca Campagna Cicala, Messina. Museo Regionale (Palermo, 1992), p. 23.

55 Principato, Badiazza, pp. 1-42.

56 "Jam ad limina Sacrae Domus Beatae Virginis de Scalis applicuit; lugubrem domum ingemmit, quam pudenter excoluit et hostis iniquitas laceravit": Bartholomaei de Neocastro, Historia Sicula (1250-1293). Rerum Italicarum scriptores II, 13/3, ed. Giuseppe Paladino (Bologna, 1921-22), p. 42.

57 Samperi, Iconologia della gloriosa vergine, pp. 314-29.

58 Principato, Badiazza, pp. 1-42. In light of the above, it is curious that, in March 1285, the Dominicans Perrone of Aidone and Antonio of Monte Gargano, who had come to Messina to instigate a revolt against the Aragonese dominion, had their abode in the monastery of Santa Maria delle Scale ("Dicti vero Fratres Praedicatores, Messanam adeuntes, latentes morabantur in domo gloriosae Virginis Mariae de Scalis inter dominas moniales": Bartholomaei de Neocastro, Historia Sicula, p. 78). 
A tradition has it that Frederick III was particularly bound to this monastery for sentimental reasons, since it was here that he met for the first time his future wife Eleanor of Anjou in May 1303 and, thereafter, he came here often to restore his spirit, away from the whirlwind of political life. ${ }^{59}$ All of this seems rather improbable due to the fact that Santa Maria della Valle is in the hinterland and not that close to Messina, while contemporary sources recount that Eleanor arrived from the coast. ${ }^{60}$ Nevertheless, the considerable restoration and remarkable reconstruction that the Aragonese king is thought to have ordered in 1303 make it highly possible that, on this occasion, he wanted to portray himself acting as a donor in the apse of the church.

Having said this, we have to note that very little is known about the dimensions and visibility of this work of art, or about the iconographic attention paid to rendering the royal image. From the report by Samperi, we know only that the king was depicted in the main apse of the church but nothing more is said. However, the same Samperi wrote that in the main apse there was also a mosaic copy of the depiction of the Madonna della Scala, probably made around $1221 .{ }^{61}$ Considering the presence of the Virgin between two cherubs, we can assume that, in respect for the Mother of God, the royal image was at a lower level of the apse and that its size was not particularly monumental. For these reasons, it is probable that the royal image was not particularly visible from the nave and aisles of the church. Moreover, we have to consider that it was in the presbyterial area, therefore in a space divided from the naves by a more or less obscuring partition - a rood screen - and to which lay people generally had no access even if some exceptions were possible. ${ }^{62}$ Consequently, said mosaic was in an

59 Agnello, L'architettura civile e religiosa, p. 253.

6o Nicolai Specialis, Historia sicula, in Bibliotheca scriptorum qui res in Sicilia gestas sub Aragonum imperio retulere, ed. Rosario Gregorio, 2 vols (Palermo, 1791-92), 1:283-508, 6.19, pp. $45^{8-59}$.

61 "Vi è in questo Tempio [namely, in the Church of Santa Maria della Valle] rimasta la copia di molto buona mano della Immagine di S. Maria della Scala, la quale stà in molta veneratione in quella contrada, e nella Tribuna maggiore, la quale era tutta artificiosamente lavorata di ricco Mosaico; vi era la Imagine di Nostra Signora adorata da due Cherubini, con alcuni caratteri greci intorno, le quali per essere logore dal tempo, non si possono perfettamente leggere; e essendo per l'humidità, e per la poco cura, caduta buona parte del Mosaico, solamente il volto della B. Vergine non hà macchia alcuna, e pare che fosse fatto di fresco, e che desse ancora spirito, e vita à quel luogo": Samperi, Iconologia della gloriosa vergine, p. 327. On the apse mosaics of this church, see also: Principato, Badiazza, pp. $165^{-68 .}$

62 Michele Bacci, Lo spazio dell'anima. Vita di una chiesa medievale (Rome, 2005); Paolo Piva, "Lo 'spazio liturgico': architettura, arredo, iconografia (nei secoli IV-XII)," in L'Arte medievale nel contesto (300-130o): funzioni, iconografia, tecniche, ed. Paolo Piva (Milan, 
area of the church that was particularly connected to the sacred liturgy, and presumably only members of the religious community could see it.

Architectural research has underlined that in the corners of the presbytery of the church there were four terraces, accessible from the outside and connected in pairs, which could be used as women's galleries. The ones on the southern side could be reached from the monastery and they were reserved for the nuns, while the ones on the northern side were accessed via a terrace situated over the aisle and connected by a drawbridge to the bell tower, which was along the side of the building and separate from the main church. ${ }^{63}$ These matronei would have been for the distinguished guests of the church who, in this way, could attend the religious services. ${ }^{64}$ Therefore, in this case, the mosaic could have been visible to the public but, all considered, limitedly to a small group of people: perhaps the king with some kin, some closer members of the court, or some foreign ambassadors, local lords, or foreign princes visiting the monastery. Moreover, these terraces do not seem to have a particularly privileged view of the apse, and therefore the royal image does not appear to have been designed to be clearly visible to those seated in these spaces.

In conclusion, once again it does not seem that the royal portrait had the specific function of spreading the image of the king among the subjects of the kingdom. Despite the monumental nature of this work, its visual impact was very far, for instance, from that of the statue of Frederick II on the gate tower of Capua, which was perfectly visible to everyone who crossed the bridge over the Volturno River to enter the city. ${ }^{65}$ Instead, the mosaic of the Church of Santa Maria della Valle was more in line with the tradition of the mosaics of William II in the Cathedral of Monreale. ${ }^{66}$

\section{The Mosaic of the Cathedral of Messina}

Guidotto de Abbiate (and not de Tabiatis), ${ }^{67}$ Archbishop of Messina from 1304 to 1333 , ordered a series of completions and improvements to the Cathedral of

2006), pp. 141-80; Donal Cooper, "Access All Areas? Spatial Divides in the Mendicant Churches of Late Medieval Tuscany," in Ritual and Space in the Middle Ages, ed. Frances Andrews (Donington, 2011), pp. 90-107.

63 Bottari, Monumenti svevi, pp. 5-6; Agnello, L'architettura civile e religiosa, p. 263.

64 Enrico Calandra, Breve storia dell'Architettura in Sicilia (Bari, 1938).

65 Vagnoni, Epifanie del corpo, pp. 94-100 (with previous bibliography).

66 Mirko Vagnoni, Dei gratia rex Sicilie. Scene d'incoronazione divina nell'iconografia regia normanna (Naples, 2017), pp. 81-128 (with previous bibliography).

67 Federico Martino, "Un dottore di decreti arcivescovo di Messina. La laurea padovana (1281) di Guidotto d'Abbiate," Rivista internazionale di Diritto Comune 4 (1993), 97-120. 
Santa Maria la Nuova in Messina: decoration of the main façade (left portal) and sacristy; encouragement for private citizens to build chapels and altars; erection of his funeral monument; and construction, on the north side of the church, of new structures for the clergy. ${ }^{68}$ However, for our purposes, his most relevant endeavour was the decoration of the main apse with mosaics (Figure. 6.4). This included: medallions with angels along the extrados; eight images of the Elders per side (Ap. 4:4) and the Agnus Dei at the high point of the intrados; and the Hetimasia and Christ enthroned and flanked by two seraphs, two angels, the Virgin, and Saint John the Baptist on the apse basin. Here, at the feet of Christ, small figures of the archbishop Guidotto, Frederick III of Aragón, and his son Peter II - identified respectively by the inscriptions "GUIDOTUS ARCHEP[ISCOPU]S / FRIDERICVS REX / PETRVS REX" - were depicted in the act of devotion. ${ }^{69}$

68 Stefano Bottari, Il duomo di Messina (Messina, 1929); Spatrisano, Lo Steri di Palermo, pp. 253-55; Enrico Pispisa, "La cattedrale di S. Maria e la città di Messina nel medioevo," in Enrico Pispisa, Medioevo Fridericiano e altri scritti (Messina, 1999), pp. 265-84.

69 Gioacchino Di Marzo, Delle belle arti in Sicilia, 4 vols (Palermo, 1858-64), 2:159; Bottari, Il duomo di Messina, pp. 26-36; Viktor Nikitič Lazarev, Storia della pittura bizantina [Istorija vizantijskoj živopisi] (Moscow, 1947-48; repr. Turin, 1967), p. 319; Giuseppe Giorgianni, “'Com'era, dov'era', conservazione e struttura nel Duomo di Messina. Gli equivoci,” 'ANAГKH. Quadrimestrale di cultura, storia e tecniche della conservazione per il progetto n.s. 26 (1999), 50-59; Pispisa, "La cattedrale di S. Maria," pp. 277-78; Gabriella Bernardi, "I mosaici del Duomo di Messina: storia e vicende conservative," in Atti del VI Colloquio dell'Associazione Italiana per lo Studio e la Conservazione del Mosaico, Venice, 20-23 January 1999, eds. Federico Guidobaldi, and Andrea Paribeni (Ravenna, 200o), pp. 439-50; Gabriella Bernardi, "I mosaici del Duomo di Messina. Nuovi documenti sui restauri," in Atti del VII Colloquio dell'Associazione Italiana per lo Studio e la Conservazione del Mosaico, Pompei, 22-25 March 20oo, ed. Andrea Paribeni (Ravenna, 2001), pp. 595-6o8; Chiara Domeneghetti, "I mosaici del duomo di Messina e Venezia," Arte. Documento. Rivista e Collezione di Storia e tutela dei Beni Culturali 15 (2001), 79-83; Grazia Musolino, "Il Duomo di Messina: sopravvivenze e ricostruzioni," Città e territorio. Documenti dell'amministrazione comunale di Messina 12/2-3 (2002), 16-21; Grazia Musolino, "I mosaici del Duomo di Messina. Un cantiere in itinere tra XIV e XVI secolo," in Palazzo Ciampoli tra arte e storia. Testimonianze della cultura figurativa messinese dal XV al XVI secolo, ed. Grazia Musolino (Soveria Mannelli, 2016), pp. 40-67. Later on, the side apses were also decorated with mosaics. The left one (ss. Sacramento) has the image of the Virgin on the throne with the Child while the Hand of God is blessing her from the Heavens. Archangels Michael and Gabriel and Saints Agatha and Lucy stand beside her, while Queen Eleanor of Anjou (wife of Frederick III as of 1302) and Queen Elisabeth of Carinthia (wife of Peter II as of 1322) are at her feet. The right one (S. Placido) has the image of Saint John the Evangelist. Saints Nicholas and Basil stand beside him while Louis of Aragón and John Duke of Randazzo, regent of the Kingdom of Sicily from 1342 to 1348 , are at his feet. However, these apses are not part of our analysis. 
Considering that Frederick III is portrayed here in prayer, historians think that the king played a prominent role in the commissioning of this work. For this reason, we can consider this image as, in some sense, an official representation of the sovereign..$^{70}$ Regarding the dating, we can assume that the work was finished before the death of Guidotto in 1333, and that its conception and creation began after 1321, when Frederick III admitted his son Peter II to the throne of Sicily - the latter is presented here with the royal title. ${ }^{71}$ However, over the centuries, the Cathedral of Messina has suffered a lot of damage and its mosaics have undergone intense restoration, in some cases being remade from scratch. ${ }^{72}$ The earthquake on 28 December 1908 did not particularly harm the main apse but the fire provoked by the bombing on 13 June 1943 produced much more serious damage. Following the report written during the survey made after the collapse, the image of Frederick III was fortunately still "intatta," ${ }^{73}$ however it was decided to completely rebuild all of the decoration of the apse. For this reason, what we currently see is the result of this remake, which, it seems, also covered the original remains. Thanks to some drawings made during the surveys in 1908 and $1943,{ }^{74}$ historians have verified that the reconstruction fundamentally followed the general iconography of the original mosaics. ${ }^{75}$ However, it must be pointed out that, in reality, the image of Frederick III underwent some inexplicable changes (Figure. 6.5). Indeed, it seems that, originally, the king was not portrayed totally kneeling down but rather in an erect position, albeit still in an attitude of reverence. Moreover, he wore a crown that did not have the current odd shape but, on the contrary, was tall and square in the manner of the other diadems represented elsewhere in the cathedral as well as in Norman iconography. ${ }^{76}$

Said this, now we will try to understand to whom the image of Frederick III was addressed. This portrait is in the presbytery of the church, and it is close to the main altar. Like the mosaic in the Church of Santa Maria della Valle, it

70 Moreover, do not forget that Frederick III often resided in Messina and that he, de facto, made this city the capital of his kingdom, in place of Palermo: Backman, Declino e caduta della Sicilia, pp. 88-89; Marrone, "La corte itinerante."

71 For a summary of this event, see: Fodale, s.v. "Federico III d'Aragona."

72 Giorgianni, "Com'era, dov'era"; Bernardi, "I mosaici del Duomo di Messina"; Bernardi, "I mosaici del Duomo"; Domeneghetti, "I mosaici del duomo"; Musolino, "Il Duomo di Messina"; Musolino, "I mosaici del Duomo di Messina".

73 Bernardi, "I mosaici del Duomo," p. 6o2.

74 Bernardi, "I mosaici del Duomo," figs. 6, 9.

75 Domeneghetti, "I mosaici del duomo," pp. 8o-81.

76 Mirko Vagnoni, Le rappresentazioni del potere. La sacralità regia dei Normanni di Sicilia: un mito?, introduction by Jean-Marie Martin (Bari, 2012), pp. 64-71. 
was in an area that was only accessible to members of the religious community and separated from the nave and aisles by a rood screen. ${ }^{77}$ Therefore, the royal image was in a context particularly bound to the liturgy. In this connection, historians have observed that the whole iconographic program of the apse followed the typical pattern of the Byzantine Deesis and that it was perfectly in line with both the funerary function of the place and the marked Marian connotation of the church and its ornamentation - on the main altar, there was an icon of the Virgin Hodegetria that was worshipped as a relic and, most likely, the mosaic decoration also had a scene of the Dormitio Virginis with the Assumption. ${ }^{78}$ Therefore, the royal image was addressed to the clergy of the cathedral as they officiated the services.

It is interesting to note that, as of 1 January 1321 and for the whole period during which the mosaics could have been created in the apse of the Cathedral of Messina, Sicily was under papal interdict. This meant that priests could not impart sacraments nor celebrate liturgical rites, and the same Frederick III asked all subjects to scrupulously observe the ban. ${ }^{79}$ However, this did not prevent members of the religious community from leading their congregations in prayer - presumably, mainly supplications aimed at absolution ${ }^{80}$ - and it could perhaps be thought that the whole mosaic had been made for this purpose. Moreover, even if there were not any religious rites underway during this period, the faithful could, in any case, have access to the church and, in this way, also lay people could see the royal portrait. Indeed, it was in a high level of the apse and it had rather monumental dimensions. For this reason, it was also visible, albeit in a not particularly evident manner, from the bottom of the nave, such that the citizens of Messina who went to the cathedral to pray could see it. In this regard, it has been noted that, starting from the Aragonese period, the cathedral regained a central role in the life of Messina and became a real symbol of the city, above all thanks to the actions of the archbishop Guidotto. ${ }^{81}$ In addition, we can observe that it seems that, during the reign of Frederick III and Peter II, this church was often used as a location for the parliaments of the kingdom..$^{82}$ In this way, the royal image could be admired by a wider audience: delegates of the city communities and nobility of the kingdom could also glimpse the portrait of their king at the bottom of the church. However, we

77 Bacci, Lo spazio dell'anima, passim; Piva, "Lo 'spazio liturgico' "; Cooper, "Access All Areas."

78 Musolino, "I mosaici del Duomo di Messina," pp. 41-42.

79 De Stefano, Federico III, p. 224; Corrado Mirto, "La monarchia e il papato," in Federico III d'Aragona, re di Sicilia, eds. Ganci et al., pp. 167-84.

8 o Backman, Declino e caduta della Sicilia, p. 180.

81 Pispisa, "La cattedrale di S. Maria," pp. $275^{-276}$, and 279.

82 Marrone, "La corte itinerante." 
should consider that, even if the image was in some way visible from the nave and aisles, it does not seem that it was specifically conceived of for this type of solution. Indeed, it was best viewed from the presbyterial area and, in reality, if its beholders had been lay people, other parts of the church would have played a more functional role and provided a more important visual impact.

In conclusion, the mosaic of the Cathedral of Messina was larger in size, had a greater visual and emotional impact, and (following its reconstruction) paid more accurate attention to rendering the iconographic details of the royal image in comparison with the other portraits of Frederick III that we have analysed. However, as a whole, it had a limited area of fruition and, in particular, it does not seem to have been designed as a means to extend an acquaintance with the royal figure among the subjects. In sum, it appears more similar (obviously, considering its peculiarities) to the iconographic tradition of the Norman mosaics of the Cathedral of Monreale ${ }^{83}$ rather than the figurative model of the Swabian statute of the Capua city gate. ${ }^{84}$

\section{Final Considerations and Conclusions}

In conclusion, following the data analysed in this paper, it does not seem that Frederick III paid particular attention to the dissemination of his image to Sicilian society and he did not implement a specific policy in order to use his portrait for political purposes or as an instrument of government aimed at stimulating acceptance of the Crown among his subjects and reinforcing his own authority. After the experience of his two Aragonese predecessors, ${ }^{85}$ it is certainly significant that he dedicated more attention to the use of his portrait.

83 Vagnoni, Dei gratia rex Sicilie, pp. 81-128 (with previous bibliography).

84 Vagnoni, Epifanie del corpo, pp. 94-100 (with previous bibliography).

85 We do not know of any images of Peter III of Aragón acting as king of Sicily. The lost wall paintings of the Cappella di Santa Maria Incoronata in Palermo date back to the 16th century: Giuseppe Bellafiore, "Edifici d'età islamica e normanna presso la Cattedrale di Palermo," Bollettino d'Arte. Ministero della Pubblica Istruzione 52/3 (1967), 178-95. And it does not seem that he made a specific seal for the Kingdom of Sicily, rather using only the seal of the king of Aragón: Sagarra, Sigillografía Catalana, 1:115-117 and 1:207-208. With regard to James II of Aragón acting as king of Sicily, we only have the images of the seal: Sagarra, Sigillografía Catalana, 1:8 and 1:240-241, n. 187; Marta Serrano-Coll, Effigies Regis Aragonum. La imagen figurativa del rey de Aragón en la Edad Media (Zaragoza, 2014), p. 82 (although the reference should be correct), and the denaro: Spahr, Le monete siciliane, p. 10; Grierson, and Travaini, Medieval European Coinage, p. 264, and 696-97, plate 42 , images n. 769-70. 
However, the decisions taken regarding the number of items, their placement, and their visibility did not follow the important innovations that Frederick II had introduced in the Kingdom of Sicily in the matter of portraiture. To the contrary, it seems that Frederick III continued the more traditional line traced by his Norman predecessor William II. Even the contemporary Sicilian chroniclers seem to confirm that the representations of Frederick III did not have a notable impact on society nor arouse specific emotions in their beholders. Indeed, not only did these authors not describe the royal images or explain the feelings that they caused in those who beheld them, but they did not even quote them in their texts.

More in general, it appears that in this period the political use of portraits in the way we understand it today - was still very uncommon. In this regard, we can recall the accusation of idolatry against Pope Boniface viII (12941303) for having placed silver and marble statues of himself in churches and on city gates. ${ }^{86}$ Moreover, we can remember that Julius von Schlosser already observed that the medieval mentality saw something idolatrous in public portraits - preferring, for this reason, to limit their use,$-{ }^{87}$ and Peter Cornelius Claussen has also pointed out that, even though we might think that official portraits were widely diffused in the Middle Ages, in reality it was only in some particular cases. ${ }^{88}$ In conclusion, it seems that the use that Frederick III made of his image within the Kingdom of Sicily was extremely different to the activity of contemporary political leaders and, in the face of a substantial iconographic absence, he probably still preferred to give his real presence the task of appearing in society, and thus carrying out his own epiphany.

\section{Bibliography}

\section{Primary Sources}

Bartholomaei de Neocastro, Historia Sicula (1250-1293). Rerum Italicarum scriptores II, 13/3, ed. Giuseppe Paladino (Bologna, 1921-22).

86 Enrico Castelnuovo, "Il significato del ritratto pittorico nella società," in Storia d'Italia, eds. Ruggiero Romano, and Corrado Vivanti, 5. I documenti 2 (Turin, 1973), pp. 1031-94, esp. 1033. On idolatry connected with images of secular power, see: Michael Camille, The Gothic Idol. Ideology and Image-Making in Medieval Art (Cambridge, Eng., 1989), pp. 291-92.

87 Julius von Schlosser, L'arte del Medioevo [Die Kunst des Mittelalters], introduction by Otto Kurz (Vienna, 1923; repr. Turin, 1989), p. 56.

88 Peter Cornelius Claussen, s.v. "Ritratto," in Enciclopedia dell'Arte Medievale 10, ed. Angiola Maria Romanini (Rome, 1999), p. 41. 
Cronaca della Sicilia di Anonimo del Trecento, ed. Pietro Colletta (Enna, 2013).

Cronache siciliane inedite della fine del Medioevo, ed. Francesco Giunta (Palermo, 1955).

Giovanni Villani, Nuova Cronica, ed. Giuseppe Porta, 3 vols (Parma, 199o-91).

Nicolai Specialis, Historia sicula, in Bibliotheca scriptorum qui res in Sicilia gestas sub Aragonum imperio retulere, ed. Rosario Gregorio, 2 vols (Palermo, 1791-92), 1:283-508.

Ryccardi de Sancto Germano notarii, Chronica. Rerum Italicarum Scriptores II, 7/2, ed. Carlo Alberto Garufi (Bologna, 1937).

\section{Secondary Sources}

Agnello, Giuseppe, "S. Maria della Valle o la 'Badiazza' in Messina," Palladio. Rivista di Storia dell'Architettura n.s. 3 (1953), 49-66.

Agnello, Giuseppe, L'architettura civile e religiosa in Sicilia nell'età sveva (Rome, 1961).

Bacci, Michele, Pro remedio animae: immagini sacre e pratiche devozionali in Italia centrale (secoli XIII e XIV) (Pisa, 200o).

Bacci, Michele, Lo spazio dell'anima. Vita di una chiesa medievale (Rome-Bari, 2005).

Backman, Clifford R., Declino e caduta della Sicilia medievale. Politica, religione ed economia nel regno di Federico III d'Aragona Rex Siciliae (1296-1337) [The decline and fall of Medieval Sicily. Politics, religion, and economy in the reign of Frederick III, 1296-1337], ed. Alessandro Musco (Cambridge, Eng., 1995; updated repr. Palermo, 2007).

Backman, Clifford R., "Federico III d'Aragona: un regno rivisitato," in Il Mediterraneo del '3oo ed il regno di Federico III d'Aragona: saperi, economia, società, Proceedings of the International Conference (Palermo-Castelbuno, 29 June - 1 July 20o6), ed. Alessandro Musco, Schede Medievali. Rassegna dell'Officina di Studi Medievali 49 (2011), pp. 7-14.

Basile, Fabio, "La chiesa di S. Maria della Valle a Messina "La Badiazza." Una datazione da rivedere," Quaderno dell'Istituto dipartimentale di architettura e urbanistica dell'Università di Catania 4 (1972), 9-34.

Bautier, Robert-Henri, s.v. "Bolla," in Enciclopedia dell'Arte Medievale 3, ed. Angiola Maria Romanini (Rome, 1992).

Becchetti, Luca, I sigilli dell'Archivio Segreto Vaticano. Nuove ricerche sfragistiche (Vatican City, 2013).

Bedos-Rezak, Brigitte Miriam, When Ego Was Imago. Signs of Identity in the Middle Ages (Leiden-Boston, 2011).

Bellafiore, Giuseppe, "Edifici d'età islamica e normanna presso la Cattedrale di Palermo," Bollettino d'Arte. Ministero della Pubblica Istruzione 52/3 (1967), 178-95.

Belting, Hans, Bild und Kult. Eine Geschichte des Bildes vor dem Zeitalter der Kunst (Munich, 1990).

Benigno, Francesco, Parole nel tempo. Un lessico per pensare la storia (Rome, 2013). 
Bernardi, Gabriella, "I mosaici del Duomo di Messina. Nuovi documenti sui restauri," in Atti del VII Colloquio dell'Associazione Italiana per lo Studio e la Conservazione del Mosaico, (Pompei, 22-25 March 200o), ed. Andrea Paribeni (Ravenna, 2001), pp. 595-6o8.

Bernardi, Gabriella, "I mosaici del Duomo di Messina: storia e vicende conservative," in Atti del VI Colloquio dell'Associazione Italiana per lo Studio e la Conservazione del Mosaico, (Venice, 20-23 January 1999), eds. Federico Guidobaldi, and Andrea Paribeni (Ravenna, 2000), pp. 439-50.

Bologna, Ferdinando, I pittori alla corte angioina di Napoli (1266-1414). E un riesame dell'arte nell'età fridericiana (Rome, 1969).

Bottari, Stefano, Il duomo di Messina (Messina, 1929).

Bottari, Stefano, Monumenti svevi di Sicilia (Palermo, 1950).

Calandra, Enrico, Breve storia dell'Architettura in Sicilia (Bari, 1938).

Camille, Michael, The Gothic Idol. Ideology and Image-Making in Medieval Art (Cambridge, Eng., 1989).

Campagna Cicala, Francesca, Il Museo regionale di Messina. Breve guida alla lettura delle opere (Messina, 1984).

Careri, Giovanni, "Louis Marin: pouvoir de la représentation et représentation du pouvoir," in Louis Marin: le pouvoir dans ses représentations, eds. Giovanni Careri, and Xavier Vert (Paris, 2008), pp. 4-15.

Castelnuovo, Enrico, "Il significato del ritratto pittorico nella società," in Storia d'Italia, eds. Ruggiero Romano, and Corrado Vivanti, 5. I documenti 2 (Turin, 1973), pp. 1031-94.

Claussen, Peter Cornelius, s.v. "Ritratto," in Enciclopedia dell'Arte Medievale 10, ed. Angiola Maria Romanini (Rome, 1999).

Codice diplomatico dei re aragonesi di Sicilia Pietro I, Giacomo, Federico II, Pietro e Ludovico dalla rivoluzione siciliana del 1282 sino al 1355, con note storiche e diplomatiche, ed. Giuseppe La Mantia, 2 vols (Palermo, 1917-56).

Colletta, Pietro, Storia, cultura e propaganda nel regno di Sicilia nella prima metà del XIV secolo: la Cronica Sicilie (Rome, 2011).

Consoli, Giuseppe, Messina. Museo Regionale (Bologna, 1980).

Cooper, Donal, "Access All Areas? Spatial Divides in the Mendicant Churches of Late Medieval Tuscany," in Ritual and Space in the Middle Ages, ed. Frances Andrews (Donington, 2011), pp. 90-107.

Daneu Lattanzi, Angela, I manoscritti ed incunaboli miniati della Sicilia, 2 vols (RomePalermo, 1965-84).

Daniele, Francesco, I regali sepolcri del Duomo di Palermo. Riconosciuti e illustrati (Naples, 1784).

De Sagarra, Ferrán, Sigillografía Catalana. Inventari, descripció i estudi dels segells de Catalunya, 3 vols (Barcelona, 1915-32). 
De Stefano, Antonino, Federico III d'Aragona re di Sicilia (1296-1337) (Palermo, 1937; repr. Bologna, 1956).

Di Marzo, Gioacchino, Delle belle arti in Sicilia, 4 vols (Palermo, 1858-64).

Di Stefano, Guido, "Larchitettura religiosa in Sicilia nel sec. XIII," Archivio storico Siciliano 4-5 (1938-1939), 39-92.

Domeneghetti, Chiara, "I mosaici del duomo di Messina e Venezia," Arte. Documento. Rivista e Collezione di Storia e tutela dei Beni Culturali 15 (2001), 79-83.

Douët d'Arcq, Louis, Collection de sceaux. Archives de l'Empire. Inventaires et documents, 3, ed. M. Le Marquis de Laborde (Paris, 1868).

Fallico, Maria Grazia, "Le fonti archivistiche (1296-1337)," in Federico III d'Aragona, re di Sicilia (1296-1337), Proceedings of the International Conference (Palermo, 27-30 November 1996), eds. Massimo Ganci, Vincenzo D’Alessandro, and Rosa Scaglione Guccione, Archivio Storico Siciliano s. IV, 23 (1997), 59-80.

Fodale, Salvatore, s.v.: "Federico III d'Aragona, re di Sicilia," in Dizionario Biografico degli Italiani 45 (Rome, 1995).

Giorgianni, Giuseppe, “'Com'era, dov'era', conservazione e struttura nel Duomo di Messina. Gli equivoci," 'ANAГKH. Quadrimestrale di cultura, storia e tecniche della conservazione per il progetto n.s. 26 (1999), 50-59.

Grierson, Philip, and Travaini, Lucia, Medieval European Coinage. With a Catalogue of the Coins in the Fitzwilliam Museum, Cambridge, 14. Italy 3. South Italy, Sicily, Sardinia (Cambridge, Eng., 1998).

Hamel, Pasquale, Il lungo regno. Vita avventurosa di Federico III, re di Sicilia (Soveria Mannelli, 2014).

Haslam, Alexander S., Reicher, Stephen D., and Platow, Michael J., The New Psychology of Leadership: Identity, Influence, and Power (Hove-New York, 2011).

Horch, Caroline, Der Memorialgedanke und das Spektrum seiner Funktionen in der bildenden Kunst des Mittelalters (Königstein im Taunus, 2001).

Il Principe invisibile. La rappresentazione e la riflessione sul potere tra Medioevo e Rinascimento, Proceedings of the International Conference (Mantua, 27-30 November 2013), eds. Lucia Bertolini, Arturo Calzona, Glauco Maria Cantarella, and Stefano Caroti, (Turnhout, 2015).

Il sarcofago dell'imperatore. Studi, ricerche e indagini sulla tomba di Federico II nella Cattedrale di Palermo. 1994-1999, 3 vols (Palermo, 2002).

Il Tabulario della Magione di Palermo (1n6-1643). Repertorio, ed. Elisabetta Lo Cascio (Rome, 2011).

I sigilli dell'Archivio Vaticano, ed. Pietro Sella, in collaboration with Marie-Hyacinthe Laurent, 2 vols (Vatican City, 1937-46).

I sigilli d'oro dell'Archivio Segreto Vaticano, ed. Aldo Martini, historical note by Martino Giusti and preface by Alessandro Pratesi (Milano, 1984). 
Lazarev, Viktor Nikitič, Storia della pittura bizantina [Istorija vizantijskoj živopisi] (Moscow, 1947-48; repr. Turin, 1967).

Le bolle d'oro dell'Archivio Vaticano, ed. Pietro Sella (Vatican City, 1934).

Le Gall, Jean-Marie, "L'impossible invisibilité du roi de France 1450-16oo," in Il Principe invisibile. La rappresentazione e la riflessione sul potere tra Medioevo e Rinascimento, Proceedings of the International Conference (Mantua, 27-30 November 2013), eds. Lucia Bertolini, Arturo Calzona, Glauco Maria Cantarella, and Stefano Caroti, (Turnhout, 2015), pp. 453-70.

Marin, Louis, Le portrait du roi (Paris, 1981).

Marin, Louis, Des pouvoirs de l'image. Gloses (Paris, 1993).

Marin, Louis, Politiques de la représentation (Paris, 2005).

Marrone, Antonino, "La corte itinerante di Sicilia negli anni 1282-1377," in Il Mediterraneo del '3oo ed il regno di Federico III d'Aragona: saperi, economia, società, Proceedings of the International Conference (Palermo-Castelbuno, 29 June - 1 July 2006), ed. Alessandro Musco, Schede Medievali. Rassegna dell'Officina di Studi Medievali 49 (2011), pp. 149-92.

Marrone, Antonino, Repertorio degli atti della Cancelleria del Regno di Sicilia dal 1282 al 1390 (Palermo, 2012).

Marrone, Antonino, I registri della R. Cancelleria e del Protonotaro del Regno di Sicilia (Palermo, 2012).

Martino, Federico, "Un dottore di decreti arcivescovo di Messina. La laurea padovana (1281) di Guidotto d'Abbiate," Rivista internazionale di Diritto Comune 4 (1993), 97-120.

Messina. Il ritorno della memoria, Catalogue of the Exhibition (Rome, Museo Nazionale di Castel Sant'Angelo, September 1994), ed. Grazia Fallico, (Palermo, 1994).

Mirto, Corrado, "La monarchia e il papato," in Federico III d'Aragona, re di Sicilia (12961337), Proceedings of the International Conference (Palermo, 27-30 November 1996), eds. Massimo Ganci, Vincenzo D’Alessandro, and Rosa Scaglione Guccione, Archivio Storico Siciliano s. IV, 23 (1997), pp. 167-84.

Monneret de Villard, Ugo, "Note d'architettura messinese," Vita d'Arte. Rivista mensile d'Arte antica e moderna 2 (1909), special issue, 71-8o.

Musolino, Grazia, "Il Duomo di Messina: sopravvivenze e ricostruzioni," Città e territorio. Documenti dell'amministrazione comunale di Messina 12/2-3 (2002), 16-21.

Musolino, Grazia, "I mosaici del Duomo di Messina. Un cantiere in itinere tra XIV e XVI secolo," in Palazzo Ciampoli tra arte e storia. Testimonianze della cultura figurativa messinese dal XV al XVI secolo, ed. Grazia Musolino (Soveria Mannelli, 2016), pp. 40-67.

Napoli, Filippo, Storia della Città di Mazara (Mazara, 1932).

Nye, Joseph, The Powers to Lead (New York, 2008). 
Olariu, Dominic, La genèse de la représentation ressemblante de l'homme. Reconsidérations du portrait à partir du XIIIe siècle (Bern, 2013).

Olivar Bertrand, Rafael, Un rei de llegenda. Frederic III de Sicilia (Barcelona, 1951).

Pace, Valentino, "Pittura bizantina nell'Italia meridionale (secoli XI-XIV)," in I Bizantini in Italia, ed. Guglielmo Cavallo (Milan, 1982), pp. 427-94.

Pastoureau, Michel, "L'État et son image emblématique," in Culture et idéologie dans la genèse de l'État moderne, Proceedings of the International Conference (Rome, $15^{-17}$ October 1984), eds. Jean-Claude Maire Vigueur, and Charles Pietri, (Rome, 1985), pp. $145^{-53}$.

Pastoureau, Michel, "Le sceau médiéval," in Michel Pastoureau, Figures et couleurs. Étude sur la symbolique et la sensibilité médiévales (Paris, 1986), pp. 71-87.

Pastoureau, Michel, "Les sceaux et la fonction sociale des images," in L'image. Fonctions et usage des images dans l'Occident médiéval, Proceedings of the 6th International Workshop on Medieval Society (Erice, 17-23 October 1992), eds. Jérôme Baschet, and Jean-Claude Schmitt, (Paris, 1996), pp. 275-308.

Perkinson, Stephen, "Rethinking the Origins of Portraiture," Gesta. International Center of Medieval Art 46/2 (2007), 135-58.

Perkinson, Stephen, The Likeness of the King. A Prehistory of Portraiture in Late Medieval France (Chicago, 2009).

Pinelli, Antonio, Sabatier, Gérard, Stollberg-Rilinger, Barbara, Tauber, Christine, and Bodart, Diane, "Le portrait du roi: entre art, histoire, anthropologie et sémiologie," Perspective. La revue de l'INHA 1 (2012), 11-28.

Pispisa, Enrico, "La cattedrale di S. Maria e la città di Messina nel medioevo," in Enrico Pispisa, Medioevo Fridericiano e altri scritti (Messina, 1999), pp. 265-84.

Piva, Paolo, "Lo 'spazio liturgico': architettura, arredo, iconografia (nei secoli IV-XII)," in L'Arte medievale nel contesto (300-130o): funzioni, iconografia, tecniche, ed. Paolo Piva (Milan, 2006), pp. 141-8o.

Principato, Antonino, Badiazza. La chiesa di S. Maria della Scala nella Valle a Messina (Messina, 1991).

Ricci, Stefano, Nesbitt, John William, and Richard, François, s.v. “Sigillo," in Enciclopedia dell'Arte Medievale 10, ed. Angiola Maria Romanini (Rome, 1999).

Salazaro, Demetrio, Studi sui monumenti dell'Italia Meridionale dal IV al XIII secolo, 2 vols (Naples, 1871-77).

Samperi, Placido, Iconologia della gloriosa vergine Madre di Dio Maria, protettrice di Messina (Messina, 1644).

Sauer, Christine, Fundatio und Memoria. Stifter und Klostergründer im Bild, 1100 bis 1350 (Göttingen, 1993).

Serrano-Coll, Marta, Effigies Regis Aragonum. La imagen figurativa del rey de Aragón en la Edad Media (Zaragoza, 2014).

Spahr, Rodolf, Le monete siciliane dagli Aragonesi ai Borboni (1282-1836) (Palermo, 1959). 
Spatrisano, Giuseppe, Lo Steri di Palermo e l'architettura siciliana del Trecento (Palermo, 1972).

Tebruck, Stefan, "Die sizilischen Klöster S. Maria in Valle Josaphat in Messina und S. Maria Latina in Agira und ihr sächsischer Fernbesitz," in Italien-MitteldeutschlandPolen. Geschichte und Kultur im europäischen Kontextvom 10. bis zum 18. Jahrhundert, eds. Wolfgang Huschner, Enno Bünz, Christian Lübke, and Sebastian Kolditz (Leipzig, 2013), pp. 361-84.

Testa, Francesco, Vita e Opere di Federico II re di Sicilia, ed. Elio Spinnato, introduction by Salvatore Fodale (original edition, De vita et rebus gestis Federici II Siciliae Regis, Palermo, 1775; Palermo, 2006).

Travaini, Lucia, s.v. "Moneta," in Enciclopedia dell'Arte Medievale 8, ed. Angiola Maria Romanini (Rome, 1997).

Travaini, Lucia, s.v. "Augustale," in Enciclopedia fridericiana 1, ed. Ortensio Zecchino (Rome, 2005).

Travaini, Lucia, s.v. "Monetazione," in Enciclopedia fridericiana 2, ed. Ortensio Zecchino (Rome, 2005).

Vagnoni, Mirko, Le rappresentazioni del potere. La sacralità regia dei Normanni di Sicilia: un mito?, introduction by Jean-Marie Martin (Bari, 2012).

Vagnoni, Mirko, Dei gratia rex Sicilie. Scene d'incoronazione divina nell'iconografia regia normanna (Naples, 2017).

Vagnoni, Mirko, Epifanie del corpo in immagine dei re di Sicilia (1130-1266), introduction by Giovanni Travagliato (Palermo, 2019).

von Schlosser, Julius, L'arte del Medioevo [Die Kunst des Mittelalters], introduction by Otto Kurz (Vienna, 1923; repr. Turin, 1989).

Zeri, Federico, and Campagna Cicala, Francesca, Messina. Museo Regionale (Palermo, 1992). 


\section{Illustrations}

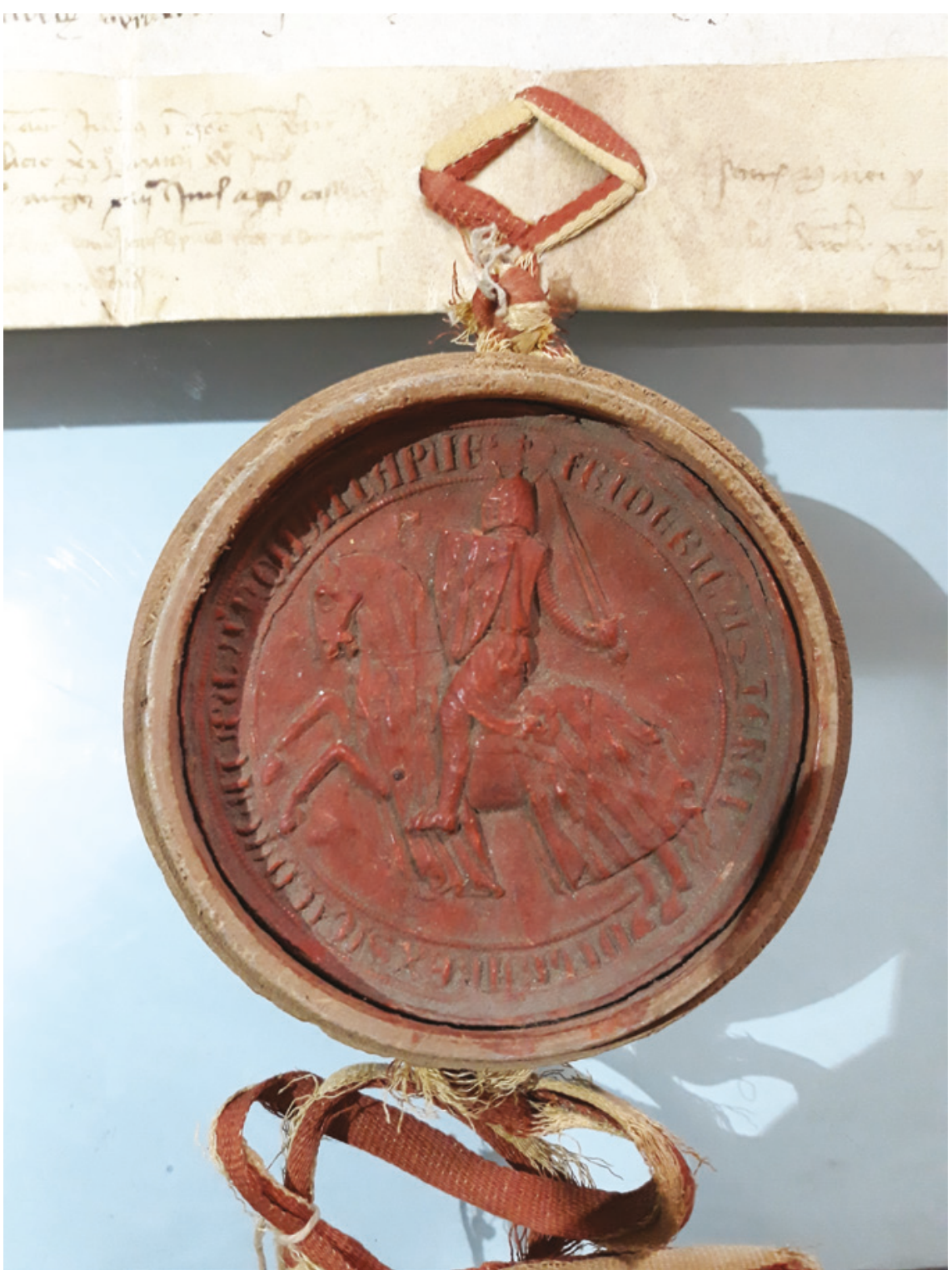

FIGURE 6.1 Seal of Frederick III of Aragón as king of Sicily, impression on red wax, 15 October 1299. Museo Civico di Caltagirone (ex Carcere Borbonico), section Pergamene della Universitas di Caltagirone, inventory number MC 4910, 10/22 1997 PHOTO TOOK BY AUTHOR 

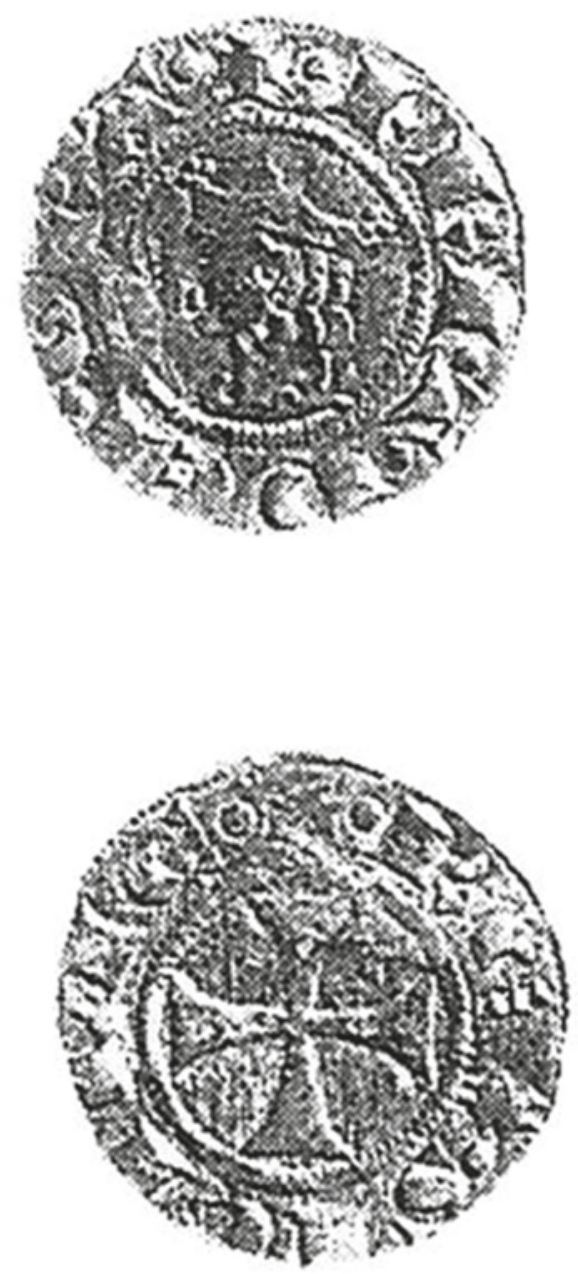

FIGURE 6.2 Denaro of Frederick III of Aragón King of Sicily, obverse and reverse of billon silver coin, 1296-1337. Reproduced with permission of the Licensor through PLSclear

IMAGE PUBLISHED IN: GRIERSON, AND TRAVAINI, MEDIEVAL EUROPEAN COINAGE, PLATE 43, IMAGE N. 780 


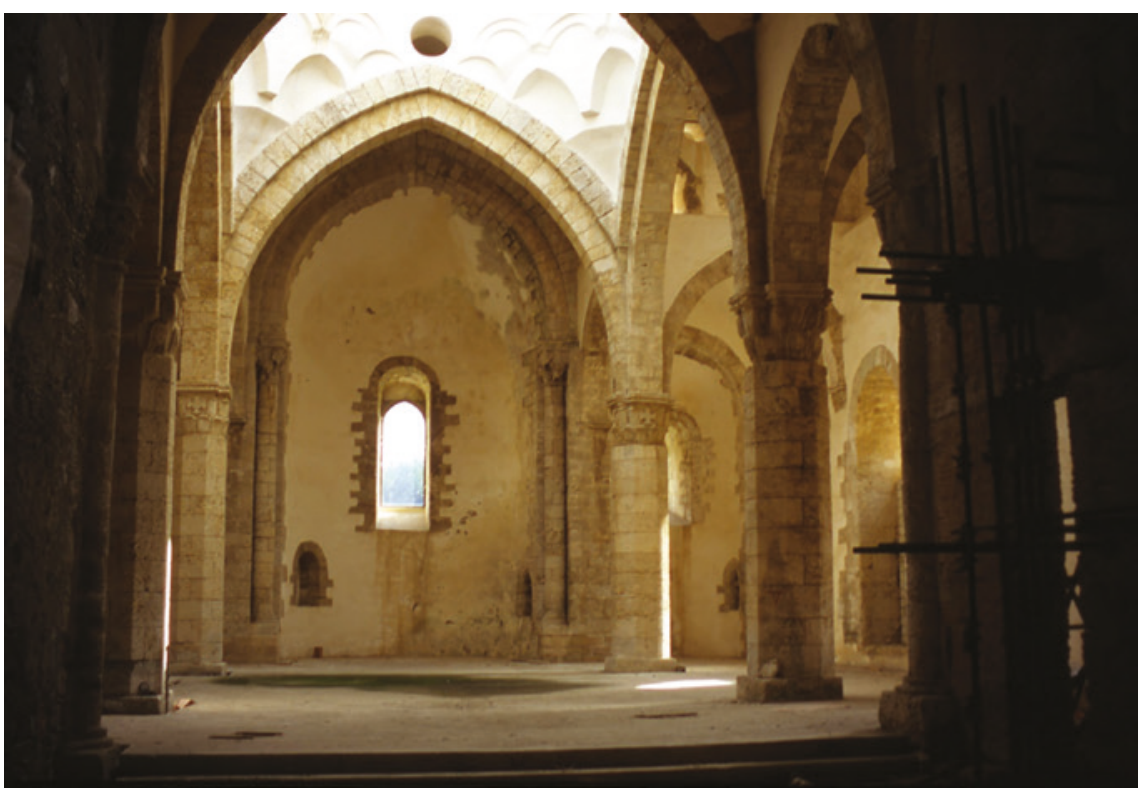

FIGURE 6.3 Church of Santa Maria della Valle (called Badiazza), central apse IMAGE COURTESY OF: HTTPS://WWW.CISTERCENSI.INFO/ABBAZIE/ABBAZIE .PHP?AB $=1165$ 


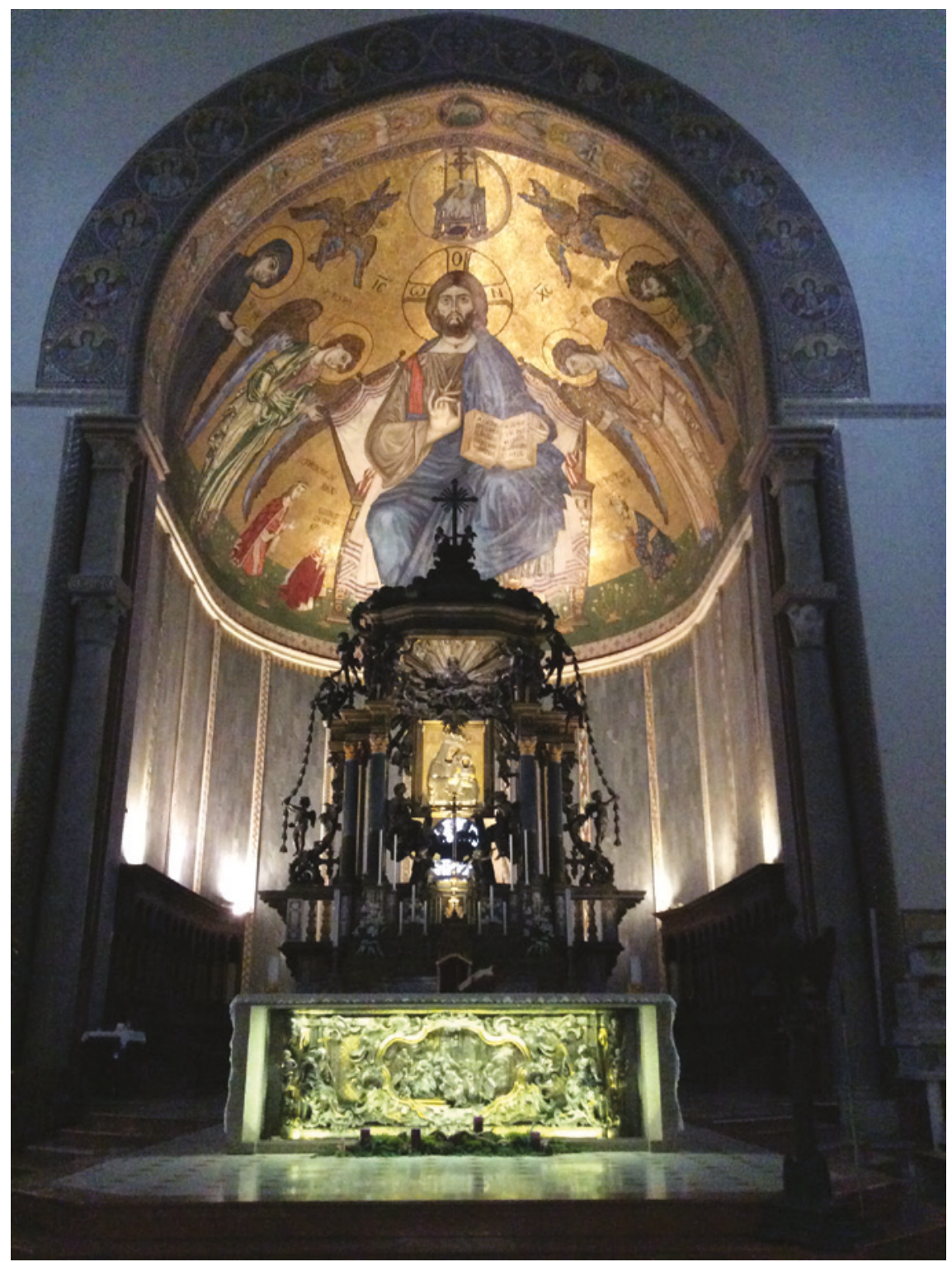

FIGURE 6.4 Cathedral of Messina, central apse Pното TоOK BY AUTHOR 


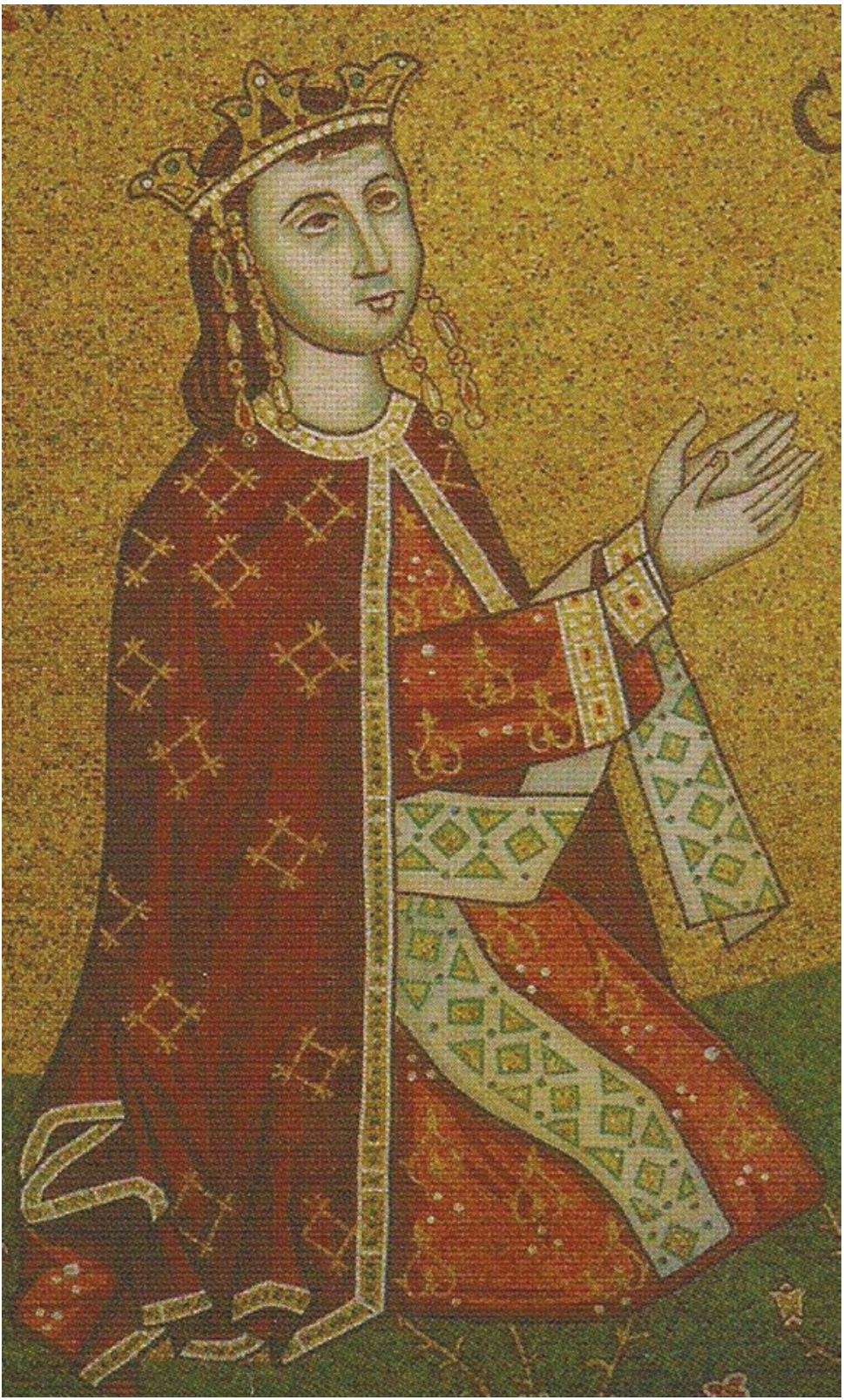

FIGURE 6.5 Detail of Frederick III of Aragón King of Sicily from the mosaics of the central apse of the Cathedral of Messina IMAGE ELABORATED BY AUTHOR 